\title{
PENGARUH MODEL PEMBELAJARAN THINK PAIR SHARE TERHADAP HASIL BELAJAR FISIKA SISWA DITINJAU DARI KETERAMPILAN BERKOMUNIKASI
}

\author{
Nova Hartika Sari \\ Feriansyah Sesunan \\ I Dewa Putu Nyeneng \\ Pendidikan Fisika, FKIP, Universitas Lampung \\ Email: novahartika14@gmail.com
}

\begin{abstract}
The research aims to find out the increased of the student's learning outcomes using think pair share in terms of skills to communicate and influence the use of think pair share against the student's learning outcomes in terms of skill to communicate. The research was carried out in class X MIPA 1 and X MIPA 3 of SMAN 13 Bandar Lampung in the academic year of 2017/2018 using the control group pretestposttest design. Results of research stated that there is an increase in the average of the student's learning outcomes on experimental class and the control class. The increase in the average of student's learning outcomes on the experimental class of 0.60 and 0.38 on the control class. The increase in both classes have a same category. Results of the research also showed that there is the influence of the use of think pair share against the student's learning outcomes with the sig value. on test two way anova of $0.00<0.05$. The average value of the skill of communicating students on classroom experiment that is larger compared to 69.71 on the class control i.e. 61.42. Overall it can be noted that the higher the skill of communicate, student's learning outcomes reached will be higher as well
\end{abstract}

Keywords: think pair share, learning outcomes, communication skill.

\section{PENDAHULUAN}

Hasil belajar merupakan suatu kemampuan yang dimiliki siswa setelah mengikuti proses belajar. Hasil belajar tersebut menyangkut semua hal yang dipelajari siswa di sekolah, baik menyangkut pengetahuan, sikap, dan keterampilan.
Keberhasilan siswa dalam belajar dapat dilihat dari kemampuannya dalam mengartikan dan menganalisis ilmu pengetahuan yang akan digunakan untuk memecahkan suatu permasalahan tertentu. Keberhasilan tersebut juga dapat dilihat dari ketercapaian indikator/tujuan pembe- 
lajaran. Namun, keberhasilan setiap siswa dalam belajar berbeda-beda.

Berdasarkan wawancara yang telah dilakukan dengan salah satu guru fisika di SMAN 13 Bandar Lampung, hasil belajar siswa pada mata pelajaran fisika ketika guru memberikan tes, $70 \%$ siswa belum mencapai kriteria ketuntasan minimal (KKM) yaitu nilai 70. Proses pembelajaran fisika yang dilakukan di SMAN 13 Bandar Lampung menggunakan beberapa metode yaitu metode diskusi, demonstrasi, dan ceramah. Proses pembelajaran tersebut belum menerapkannya sebuah model pembelajaran, hal tersebutlah yang mungkin menyebabkan hasil belajar fisika siswa rendah.

Penggunaaan model pembelajaran pada proses belajar dapat memberikan suasana baru yang dapat memotivasi minat siswa dalam belajar, sehingga hasil belajar yang dicapai menjadi meningkat. Model pembelajaran yang dapat digunakan untuk meningkatkan hasil belajar yaitu model pembelajaran think pair share dan model pembelajaran langsung (direct instruction).

\section{Model pembelajaran Think pair share}

Model pembelajaran think pair share merupakan suatu cara yang efektif untuk membuat variasi suasana diskusi kelas. Prosedur yang digunakan dalam think pair share dapat memberikan siswa banyak waktu untuk berpikir, merespon, dan saling membantu sesama siswa. Langkah-langkah secara umum dalam penerapan think pair share seperti yang diungkapkan oleh Arend dalam Trianto (2011:81-82) yaitu: berpikir (thinking), berpasangan (pairing), dan berbagi (sharing).

Langkah-langkah pembelajaran think pair share ini menuntut siswa untuk berpartisipasi secara aktif dalam mengungkapkan ide/gagasan, sehingga dapat menumbuhkan rasa percaya diri siswa. Siswa juga lebih banyak berinteraksi dengan siswa lainnya dalam mendiskusikan permasalahan/materi pembelajaran, sehingga membuat siswa belajar dengan pasangan diskusinya sebelum mengemukakan idenya di depan kelas. Langkah pembelajaran ini juga dapat menjadikan siswa lebih berani 
dalam mengungkapkan ide/gagasan di depan kelas.

\section{Model Pembelajaran Langsung}

\section{(Direct instruction)}

Model pembelajaran langsung adalah suatu pembelajaran yang langkah-langkahnya dapat menuntun siswa dalam memahami suatu materi yang berkaitan dengan pengetahuan deklaratif dan pengetahuan prosedural secara terstruktur.

Menurut Shoimin (2014: 64-65) pada model pembelajaran direct instruction terdapat lima fase yang sangat penting. Sintaks model tersebut disajikan dalam lima tahap antara lain: (1) Fase orientasi/menyampaikan tujuan, (2) Fase presentasi/Demonstrasi, (3) Fase latihan terbimbing, (4) Fase mengecek pemahaman dan memberikan umpan balik, (5) Fase latihan mandiri.

Menurut Sanjaya dalam Hamka dan Arsyad (2015), keunggulan pembelajaran langsung adalah guru dapat mengontrol urutan dan keluasan materi pembelajaran. Berdasarkan keunggulan tersebut guru dapat mengetahui pemahaman siswa mengenai materi yang disampaikan, guru juga dapat mengontrol materi pembelajaran yang diberikan agar hasil belajar yang dicapai oleh siswa menjadi maksimal.

Penggunaan model pembelajaran think pair share pada kelas eksperimen dapat meningkatkan hasil belajar fisika siswa. Model think pair share memiliki tahapan yaitu thinking, pairing, dan sharing. Tahap pertama yaitu thinking, pada tahap ini siswa diberikan waktu untuk berpikir sendiri tentang permasalahan yang diberikan, kemudian pada tahap pairing siswa akan berdiskusi dengan teman sebangkunya dan saling memberikan masukan satu sama lain sehingga pengetahuannya akan lebih sempurna, dan selanjutnya pada tahap sharing siswa yang mendapatkan kesempatan untuk menjelaskan permasalahan di depan kelas akan merasa bertanggung jawab atas hasil dari diskusi dengan pasangannya. Akibatnya hasil belajar yang diperoleh siswa akan menjadi lebih baik.

Model pembelajaran yang digunakan pada kelas kontrol yaitu model pembelajaran langsung. Proses pembelajaran pada kelas kontrol siswa dibagi menjadi beberapa 
kelompok yang terdiri dari 4-5 siswa. Kelompok tersebut akan berdiskusi tentang permasalahan yang diberikan tanpa melalui proses belajar sendiri terlebih dahulu, sehingga dalam proses diskusi ada siswa yang tidak aktif memberikan masukan, mencatat, dan tidak mempersiapkan diri untuk menjelaskan materi di kelasnya. Akibatnya hasil belajar yang diperoleh akan lebih rendah dibandingkan dengan kelas yang mengunakan model pembelajaran think pair share.

Proses pembelajaran memerlukan interaksi antar siswa. Interaksi tersebut dapat berupa komunikasi antar siswa yang dapat meningkatkan rasa percaya diri, dan dapat membantu satu sama lain. Keterampilan berkomunikasi pada setiap proses pembelajaran memiliki peranan yang sangat penting. Komunikasi yang baik dapat memudahkan siswa dalam mengemukakan ide atau gagasan yang mereka pikirkan, sehingga diharapkan dapat memahami materi yang diberikan oleh guru. Levy (2009) menyatakan bahwa keterampilan berkomunikasi merupakan ke- terampilan dasar yang harus dimiliki peserta didik untuk memahami sebuah materi. Siswa yang memiliki keterampilan komunikasi tinggi maka akan tinggi pula hasil belajar siswa.

Keterampilan berkomunikasi dapat dinilai pada dua aspek yaitu lisan dan tertulis. Indikator keterampilan berkomunikasi secara lisan yang dapat digunakan diantaranya: (a) Menyampaikan pendapatnya mengenai permasalahan yang diberikan, (b) Menanggapi jawaban dari siswa lain, (c) Mengungkapkan apa yang ingin diketahui, (d) Menyimpulkan penyelesaian permasalahan menggunakan bahasanya sendiri. Indikator keterampilan berkomunikasi secara tertulis yang dapat digunakan diantaranya: (a) Menyajikan laporan/tugas, (b) Menjawab permasalahan/soal evaluasi.

Tujuan pada penelitian ini adalah mengetahui bagaimana peningkatan hasil belajar fisika siswa setelah diterapkan model pembelajaran think pair share ditinjau dari keterampilan berkomunikasi dan mengetahui bagaimana pengaruh penggunaan model pembelajaran think pair share 
ditinjau dari keterampilan ber- pada penelitian ini menggunakan komunikasi. teknik Purposive Sampling. Sampel yang dipilih adalah siswa kelas $\mathrm{X}$

\section{METODE}

Penelitian ini merupakan studi eksperimen dengan populasi yaitu seluruh siswa kelas X IPA SMAN 13 Bandar Lampung pada semester ganjil tahun pelajaran 2017/2018. IPA1 dengan jumlah 29 siswa sebagai kelas eksperimen dan siswa kelas X IPA3 dengan jumlah 26 siswa sebagai kelas kontrol. Desain penelitian menggunakan rancangan Teknik dalam pengambilan sampel

Tabel 1. Matriks Rancangan Anova Dua Jalur

\begin{tabular}{cccc}
\hline $\mathrm{E}$ & $\mathrm{O}_{1}$ & $\mathrm{X}$ & $\mathrm{O}_{2}$ \\
\cline { 2 - 4 } $\mathrm{K}$ & $\mathrm{O}_{3}$ & $\mathrm{Y}$ & $\mathrm{O}_{4}$ \\
\hline
\end{tabular}

Keterangan:

$\begin{array}{ll}\mathrm{E} & =\text { kelas eksperimen } \\ \mathrm{K} & =\text { kelas kontrol } \\ \mathrm{O} 1, \mathrm{O} 3 & =\text { Pretest } \\ \mathrm{O} 2, \mathrm{O} 4 & =\text { Posttest } \\ \mathrm{X} & =\text { Model Pembelajaran Think pair share } \\ \mathrm{Y} & =\text { Model Pembelajaran Langsung }\end{array}$

Penelitian ini memiliki komponen kedua yaitu peninjau beberapa komponen. Komponen (keterampilan berkomunikasi), dan pertama yaitu model pembelajaran komponen ketiga yaitu hasil belajar yang digunakan (model sebagai variabel terikat.

pembelajaran think pair share pada Pertama-tama data pretest dan kelas eksperimen dan model posttest diuji dengan $N$-gain untuk pembelajaran langsung pada kelas mengetahui apakah ada peningkatan kontrol) sebagai variabel bebas, hasil belajar setelah diterapkannya 
model pembelajaran think pair rumusan masalah yaitu ada atau share. Kemudian rata-rata $N$-gain tidaknya peningkatan dan pengaruh hasil belajar siswa yang diperoleh dianalisis dengan uji normalitas dan homogenitas, apakah data yang diperoleh berdistribusi normal dan homogen. Setelah diketahui data berdistribusi normal dan homogen, data dianalisis dengan uji two way anova, untuk mengetahui apakah ada interaksi antar faktor yang diteliti dan apakah ada pengaruh signifikan model pembelajaran dan keterampilan berkomunikasi terhadap hasil belajar. Data yang telah di uji two way anova, kemudian diuji kembali dengan menggunakan uji independent sampel t-test. Uji tersebut digunakan untuk mengetahui perbedaan pengaruh antara model pembelajaran pada kelas eksperimen dan model pembelajaran pada kelas kontrol. Uji independent sampel ttest juga digunakan untuk mengetahui perbedaan rata-rata hasil belajar pada kelas eksperimen dan kelas kontrol.

\section{HASIL DAN PEMBAHASAN}

Penelitian yang telah dilakukan dimaksudkan untuk menjawab terhadap hasil belajar yang diakibatkan oleh penggunaan model pembelajaran think pair share ditinjau dari keterampilan berkomunikasi. Sebelum penelitian dilakukan, instrumen tes yang digunakan harus melalui pengujian validitas, reliabilitas, dan tingkat kesukaran terlebih dahulu. Hasil uji validitas menunjukkan bahwa dari 10 soal vektor, terdapat 9 soal yang valid dengan hasil pearson correlation > 0,30. Berdasarkan hasil uji validitas yang telah dilakukan, dari 9 soal yang valid dipilih 5 soal yang akan diuji dengan uji reliabilitas untuk mengetahui soal bersifat reliabel. Hasil uji reliabilitas menunjukkan bahwa soal bersifat reliabel dengan hasil cronbach's alpha $>0,40$. Hasil uji tingkat kesukaran menunjukkan bahwa soal memiliki tingkat kesukaran sedang dan sukar.

Penelitian ini diajukan dua hipotesis, hipotesis pertama diuji menggunakan uji $N$-gain. Hipotesis kedua diuji menggunakan uji normalitas, uji homogenitas, uji two way anova, dan uji independent sampel t-test 
Peningkatan Hasil Belajar Siswa belajaran think pair share dapat Setelah Digunakannya Model dilihat dari selisih hasil pretest dan Pembelajaran Think pair share hasil posttest. Data rata-rata $N$-gain Ditinjau dari Keterampilan hasil belajar siswa ditunjukkan pada Berkomunikasi Tabel 2.

Peningkatan hasil belajar fisika siswa setelah diterapkan model pem-

Tabel 2. Data Rata-rata $N$-gain Hasil Belajar

\begin{tabular}{lcc}
\hline \multicolumn{1}{c}{ Perolehan Skor } & Kelas Eksperimen & Kelas Kontrol \\
\hline Gain Tertinggi & 80 & 72 \\
Gain Terendah & 20 & 20 \\
Rata-rata Gain & 56,77 & 35,45 \\
Rata-rata $N$-gain & 0,60 & 0,38 \\
Kategori & Sedang & Sedang \\
\hline
\end{tabular}

Berdasarkan data yang disajikan pada Tabel 2, dapat diketahui bahwa rata-rata $N$-gain hasil belajar pada kelas eksperimen memiliki nilai yang lebih tinggi dibandingkan dengan rata-rata $N$-gain hasil belajar pada kelas kontrol. Artinya model pembelajaran think pair share yang digunakan pada kelas eksperimen mampu memberikan peningkatan yang lebih baik pada hasil belajar siswa dibandingkan dengan model pembelajaran langsung. Hasil perhitungan menunjukkan bahwa ratarata $N$-gain hasil belajar pada kelas eksperimen sebesar 0,60 dan N-gain hasil belajar pada kelas kontrol diperoleh nilai sebesar 0,38.

Peningkatan hasil belajar siswa ini diakibatkan oleh pembelajaran yang telah diterima siswa. Pembelajaran tersebut dilakukan dengan menggunakan model pembelajaran think pair share. Model pembelajaran think pair share ini menjadikan siswa lebih aktif dan lebih mengingat materi/ permasalahan yang sedang dibahas. Langkah-langkah pada model pembelajaran think pair share menjadikan siswa terbiasa ber- 
kolaborasi dengan siswa lain, masingmasing siswa juga merasa bertanggung jawab atas hasil yang diperolehnya sehingga siswa termotivasi untuk mendapatkan hasil belajar yang lebih baik. Hal tersebut sesuai dengan pendapat yang menyatakan bahwa setiap siswa bertanggung jawab untuk menguasai materi dengan cara berpikir sendiri terlebih dahulu, bertukar informasi dengan teman sekelompoknya, sehingga siswa yang pasif dan hanya mendengarkan saja tidak ditemukan lagi pada pembelajaran ini, melainkan peserta didik menjadi aktif untuk belajar (Pangkali., Sinon., \& Widyaningsih, 2016).

Penerapan model pembelajaran think pair share membuat diskusi siswa lebih berjalan optimal, memberikan lebih banyak kesempatan bagi siswa untuk bertanya, memberikan ide dan bertukar pendapat, karena satu kelompok hanya beranggotakan dua orang. Sehingga kontribusi siswa yang muncul lebih banyak dan bagi siswa yang tidak mau bertanya langsung pada guru tentang materi yang kurang dipahaminya dapat bertanya kepada pasangannya, dengan demikian pemahaman siswa tentang materi menjadi lebih baik sehingga berdampak positif terhadap hasil belajar yang akan menjadi lebih baik (Nisa., Musdi.,\& Jazwinarti, 2014). Hal lain juga diungkapkan oleh Nugrahanggraini dan Budiningarti (2014) bahwa penggunaan model pembelajaran think pair share dapat meningkatkan hasil belajar siswa.

Peningkatan hasil belajar setelah digunakannya model pembelajaran think pair share ditinjau dari keterampilan berkomunikasi pada kelas eksperimen lebih baik dibandingkan dengan kelas kontrol. Grafik yang menunjukkan rata-rata $N$-gain hasil belajar ditinjau dari keterampilan berkomunikasi dapat dilihat pada Gambar 1.

Berdasarkan grafik pada Gambar 1 dapat dilihat bahwa pada kategori keterampilan berkomunikasi tinggi rata-rata $\mathrm{N}$-gain hasil belajar kelas eksperimen lebih tinggi dibandingkan dengan rata-rata $N$-gain hasil belajar kelas kontrol, begitu pula pada kategori keterampilan berkomunikasi sedang dan rendah. Hal tersebut dikarenakan siswa yang 
memiliki keterampilan berkomu- didik untuk berdiskusi, mencari nikasi yang baik akan lebih mudah informasi, menganalisis dan dalam memahami materi pembe- mengevaluasi data serta membuat lajaran dan ia akan lebih mudah laporan, sehingga dapat mempemenyampaikan ide/gagasan serta ngaruhi prestasi belajar. Fitria (2014) mudah dalam berdiskusi dengan menyatakan bahwa semakin tinggi temannya, sehingga hasil belajar yang dicapainya akan lebih baik. Hal tersebut dibuktikan oleh Noviyanti (2011) yang menyatakan bahwa keterampilan berkomunikasi yang kemampuan berkomunikasi, maka semakin tinggi pula prestasi belajar, sebaliknya semakin rendah kemampuan komunikasi maka semakin rendah pula prestasi belajarnya. tinggi akan mempermudah peserta

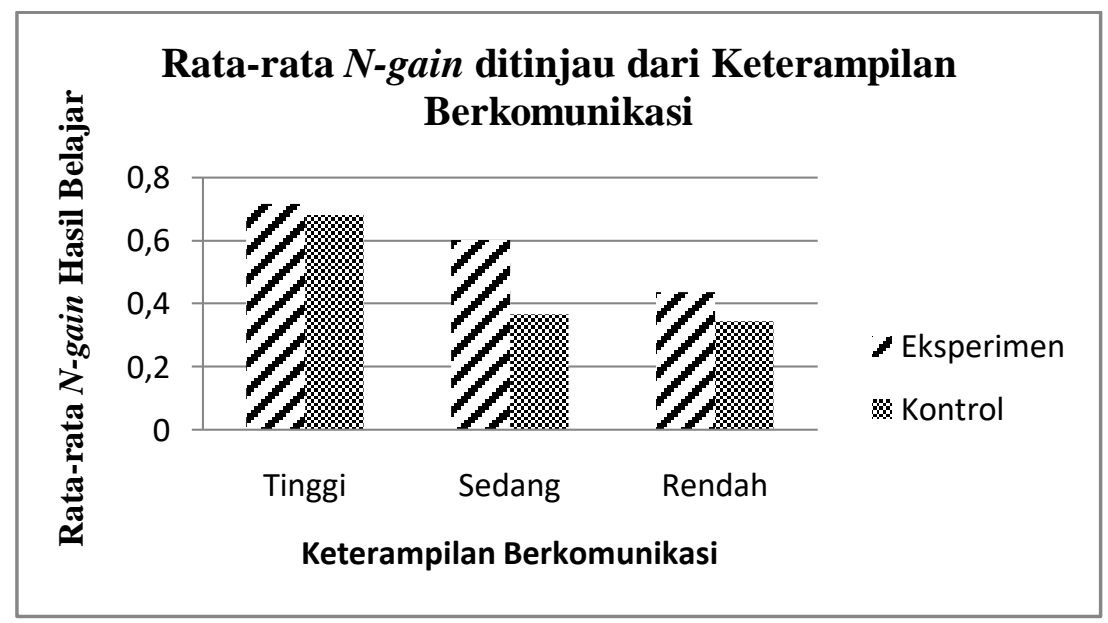

Gambar 1. Rata-rata $N$-gain hasil belajar ditinjau dari keterampilan berkomunikasi

$\begin{array}{cll}\text { Pengaruh Penggunaan Model } & \text { terhadap hasil belajar siswa ditinjau } \\ \text { Pembelajaran Think pair share } & \text { dari keterampilan berkomunikasi } \\ \text { terhadap Hasil Belajar Siswa Ditinjau } & \text { dapat diketahui dengan menguji data } \\ \text { dari Keterampilan Berkomunikasi } & \text { rata rata peningkatan hasil belajar } \\ \text { Pengaruh penggunaan model } & \text { siswa }(N \text {-gain }) . \\ \text { pembelajaran think pair share } & \end{array}$


Data rata-rata $N$-gain siswa diuji dengan uji kolmogorov smirnov terlebih dahulu, untuk mengetahui data berdistribusi normal atau tidak. Hasil uji tersebut menunjukkan nilai asymp.sig (2-tailed) lebih besar dari 0,05, masing-masing pada kelas eksperimen dan pada kelas kontrol yaitu 0,914 dan 0,826 , sehingga dapat disimpulkan bahwa data $N$-gain pada kedua kelas berdistribusi normal. Data $N$-gain selanjutnya diuji dengan uji homogenitas, untuk mengetahui kesamaan varians pada kelas eksperimen dan kelas kontrol. Hasil uji tersebut menunjukkan nilai sig. lebih besar dari 0,05 yaitu 0,925, yang artinya data $N$-gain kelas eksperimen dan kelas kontrol bersifat homogen.

Data rata-rata $N$-gain hasil belajar selanjutnya diuji menggunakan uji two way anova untuk mengetahui interaksi antar faktor yang diteliti dan adanya pengaruh model pembelajaran yang digunakan. Hasil uji two way anova ditunjukkan pada Tabel 3.

Tabel 3. Hasil Uji Two way anova $N$-gain Hasil belajar

\begin{tabular}{lll}
\hline Parameter & Sig. & Keterangan \\
\hline Kelas & 0,00 & Berpengaruh signifikan \\
Keterampilan Berkomunikasi & 0,01 & Berpengaruh signifikan \\
Kelas*Keterampilan Berkomunikasi & 0,66 & Tidak Ada Interaksi \\
\hline
\end{tabular}

Berdasarkan hasil pada Tabel 3 dapat diketahui pada variabel kelas (model pembelajaran) dan keterampilan berkomunikasi berpengaruh signifikan, artinya model pembelajaran yang digunakan pada saat proses pembelajaran dan keterampilan berkomunikasi yang dimiliki oleh siswa berpengaruh terhadap hasil belajar siswa. Model pembelajaran terhadap keterampilan berkomunikasi memiliki nilai sig.>0,05, yang artinya tidak ada interaksi antara model pembelajaran dan keterampilan berkomunikasi.

Data $N$-gain hasil belajar siswa diuji kembali menggunakan uji independent sampel t-test untuk mengetahui perbedaan rata-rata $N$ gain hasil belajar pada kelas eksperimen dan kelas kontrol dan untuk mengetahui model pembelajaran manakah yang berpengaruh lebih besar terhadap hasil belajar. 
Hasil uji independent sample t-test ditunjukkan pada Tabel 4.

Tabel 4. Hasil Uji Independent Sample T-Test N-gain Hasil belajar

\begin{tabular}{cccc}
\hline Kelas & Mean & Mean Difference & Sig (2-tailed) \\
\hline Eksperimen & 0,6035 & 0,22467 & 0,000 \\
Kontrol & 0,3788 & 0 & \\
\hline
\end{tabular}

Berdasarkan data yang disajikan pada Tabel 4 menunjukkan bahwa terdapat perbedaan rata-rata $N$-gain hasil belajar pada kedua kelas sebesar 0,22467. Mean pada kelas eksperimen lebih tinggi dibandingkan dengan mean pada kelas kontrol, masingmasing yaitu 0,6035 yaitu 0,3788 , sehingga dapat disimpulkan bahwa pengaruh model pembelajaran think pair share lebih besar dibandingkan dengan model pembelajaran langsung (direct instruction).

Perbedaan rata-rata $N$-gain hasil belajar dikarenakan pada kelas eksperimen menggunakan model pembelajaran think pair share, sedangkan pada kelas kontrol menggunakan model pembelajaran langsung (direct instruction). Hal tersebut dibuktikan oleh penelitian Rahayu dan Pramukantoro (2013) bahwa hasil belajar siswa yang menggunakan model pembelajaran think pair share lebih tinggi daripada hasil belajar siswa yang menggunakan model pembelajaran langsung. Menurut Dewi et al. (2014) perbedaan hasil belajar yang signifikan dipengaruhi oleh model pembelajaran think pair share, karena model ini memberikan kesempatan kepada siswa untuk mengembangkan kemampuan berpikir logis, analitis, sistematis, kreatif, dan kritis, yang akhirnya bermuara pada hasil belajar yang maksimal. Keterampilan berkomunikasi memiliki beberapa kriteria yaitu tinggi, sedang, dan rendah. Kriteria keterampilan berkomunikasi siswa terhadap ratarata $N$-gain hasil belajar ditunjukkan pada Tabel 5.

Berdasarkan Tabel 5 dapat diketahui bahwa siswa yang memiliki kriteria keterampilan bekomunikasi tinggi, maka hasil belajar yang diperolehnya pun akan tinggi. Keterampilan berkomunikasi yang dimiliki oleh setiap siswa akan 
mempengaruhi hasil belajar yang dicapainya. Hal tersebut sesuai dengan penelitian Afiani (2016) bahwa terdapat pengaruh yang signifikan kemampuan komunikasi terhadap prestasi belajar siswa.
Anggraeni et al. (2014) menyatakan bahwa siswa yang mempunyai kemampuan komunikasi tinggi hasil belajarnya lebih baik daripada siswa yang mempunyai kemampuan komunikasi rendah.

Tabel 5. Rata-rata $N$-gain Hasil Belajar Ditinjau dari Keterampilan

Berkomunikasi

\begin{tabular}{rcc}
\hline Keterampilan & \multicolumn{2}{c}{ Rata-rata $N$-gain Hasil Belajar } \\
\cline { 2 - 3 } Berkomunikasi & Eksperimen & Kontrol \\
\hline Tinggi & 0,7181 & 0,6820 \\
Sedang & 0,6026 & 0,3679 \\
Rendah & 0,4368 & 0,3448 \\
\hline
\end{tabular}

\section{PENUTUP}

\section{Kesimpulan}

Berdasarkan hasil penelitian dan pembahasan, dapat ditarik dua buah simpulan sebagai berikut. (1) Ada peningkatan hasil belajar siswa pada kelas yang menggunakan model pembelajaran think pair share (eksperimen) dan kelas yang tidak menggunakan model pembelajaran think pair share (kontrol). Rata-rata $N$-gain pada kelas eksperimen lebih tinggi daripada kelas kontrol. (2) Ada pengaruh penggunaan model pembelajaran think pair share terhadap hasil belajar ditinjau dari keterampilan berkomunikasi. Semakin tinggi keterampilan berkomu- nikasi siswa maka akan semakin tinggi pula hasil belajarnya.

\section{Saran}

Berdasarkan Pembelajaran menggunakan model pembelajaran think pair share dapat dijadikan sebagai model pembelajaran alternatif yang dapat meningkatkan hasil belajar siswa dan keterampilan komunikasi setiap siswa harusnya menjadi hal penting yang diperhatikan oleh setiap guru, agar hasil belajar yang diperoleh siswa menjadi meningkat.

\section{DAFTAR PUSTAKA}

Afiani, N. 2016. Pengaruh Kemampuan Komunikasi Matematis dan Kemandirian Belajar terhadap Prestasi Belajar 
Matematika. JKPM. Vol 2 (1): 113

Anggraeni, V. T., Sutama, dan Samino. 2014. Dampak Komunikasi Siswa terhadap Hasil Belajar Matematika Sekolah Dasar. Jurnal Varia Pendidikan. 26 (1): 69-76

Dewi, D. A. L., Zulaikha, S., dan Wiyasa, I. K. N. 2014. Pengaruh Model Pembelajaran Kooperatif Tipe TPS Berbantuan Media Lingkungan terhadap Hasil Belajar IPA Siswa Kelas V SD Gugus III Gianyar. Jurnal Mimbar PGSD Universitas Pendidikan Ganesha. 2 (1): $1-10$

Fitria, A. 2014. Pengaruh Kemampuan Komunikasi Interpersonal terhadap Prestasi Belajar Matematika Siswa SMP Kemala Bhayangkari Medan Tahun 2014/2015. Jurnal Mantik Penusa. 15 (1): 1-11

Hamka, L., Arsyad, M. N. 2015.

Keefektifan Penerapan Model Pembelajaran Langsung pada Materi Sistem Gerak di SMA Negeri Donri-Donri. Jurnal Bionacture. 16 (1): 58-64

Levy. 2009. Teaching Scientific Communication Skills in Science Studies: Does it Make A Difference. International Journal of Science and Mathematics Education. 7: 875-903.

Nisa, R., Musdi, E., dan Jazwinarti. 2014. Penerapan Pembelajaran Kooperatif Tipe Think pair share pada Pembelajaran Matematika di Kelas XI IPS SMAN 2 Padang Panjang. Jurnal pendidikan matematika. 3 (1): 23-28

Noviyanti, M. 2011. Pengaruh Motivasi dan Keterampilan Berkomunikasi terhadap Prestasi
Belajar Mahasiswa pada Tutorial Online Berbasis Pendekatan Kontekstual pada Matakuliah Statistika Pendidikan. Jurnal Pendidikan. 12 (2): 80-81

Nugrahanggraini, P. S., Budiningarti, H. 2014. Pengaruh Penerapan Pembelajran Kooperatif Tipe TPS (Think pair share) dengan Teknik Card Sort pada Materi Fluida Statik terhadap Hasil Belajar Siswa Kelas XI SMAN 1 Puri Mojokerto. Jurnal Inovasi Pendidikan Fisika. Vol 3 (2): 65-69

Pangkali, T., Sinon, I. L.S., dan Widyaningsih, S. W. 2016. Penerapan Model Kooperatif Tipe TPS terhadap Hasil Belajar dan Aktivitas Peserta Didik pada Materi Gelombang Mekanik Kelas XI IPA SMAN 1 Kabupaten Sorong. Jurnal Ilmiah Pendidikan Fisika Al-BiRuNi. 5 (2): 173-181

Rahayu, A., Pramukantoro, J.A. 2013. Pengaruh Model Pembelajaran Think pair share dengan Strategi Index Card Match terhadap Hasil Belajar Siswa pada Standar Kompetensi Menerapkan Dasardasar Elektronika di SMKN 1 Madiun. Jurnal Pendidikan Teknik Elektro. 2 (3): 991-999

Shoimin, A. 2014. 68 Model Pembelajaran Inovatif dalam Kurikulum 2013. Yogyakarta: Arruzz media.

Trianto. 2011. Mendesain Model Pembelajaran Inovatif, Progresif, Konsep, Landasan, dan Implementasinya Pada Kurikulum Tingkat Satuan Pendidikan KTSP). Jakarta: Kencana. 